\title{
Cryptococcus albidus var. albidus Isolated from Turquoise-Fronted Parrots (Amazona aestiva: Psittacidae) Kept in Captivity: A Probable Reservoir Ecological of Fungal Specimen
}

\author{
Diana Costa Nascimento ${ }^{1}$, Claudete Rodrigues Paula ${ }^{2}$, Luciana da Silva Ruiz ${ }^{3}$, Carina Domaneschi², Bianca Silva Navarro ${ }^{2}$, Francisco de \\ Assis Baroni ${ }^{4}$, Reinaldo Bolognini Orsi ${ }^{1}$, Marcia de Souza Carvalho Melhem ${ }^{5}$ and Diniz Pereira Leite Jr ${ }^{2,6,7 *}$ \\ ${ }^{1}$ Universidade Paulista (UNIP), Rua Pedro Domingos Vitale, 644, Parque Itália, Campinas-SP, Brazil \\ ${ }^{2}$ School of Dentistry, Universidade de São Paulo (USP), Av. Lineu Prestes, 2.227, São Paulo-SP, Brazil \\ ${ }^{3}$ Section of Mycology, Instituto Adolfo Lutz (IAL), Avenida Dr. Enéas Carvalho de Aguiar, 188, São Paulo-SP, Brazil \\ ${ }^{4}$ Universidade Federal Rural do Rio de Janeiro (UFRRJ), Rodovia BR 465, Km 07, s/n, Zona Rural, Seropédica, Rio de Janeiro-RJ, Brazil \\ ${ }^{5}$ Section of Biomedical Sciences, Mycology Laboratory, Instituto Adolfo Lutz (IAL), Rua Rubens Arruda, s/n, quadra 06, Bauru-SP, Brazil \\ ${ }^{6}$ Laboratory of Investigation, Mycology Laboratory, Faculty of Medicine, Universidade Federal de Mato Grosso (UFMT), Av. Fernando Corrêa da Costa 2367, Cuiabá-MT, \\ Brazil \\ ${ }^{7}$ Centro Universitário de Várzea Grande (UNIVAG), Research Laboratory, Av. Dom Orlando Chaves, Várzea Grande-MT, Brazil
}

\begin{abstract}
Cryptococcus is an opportunistic yeast that causes life-threatening infections as meningoencephalitis primarily in immunocompromised hosts, generally associated with AIDS. The source of this organism is mainly pigeon excreta; however, other avian species' excreta are implicated as a source of this yeast. The aim of this study was to perform the isolation of yeasts of the Cryptococcus genus from the cloacae of 40 parrots kept in captivity area of the genus Amazona aestiva. These birds were anesthetized, the cloacae washed, and then swabs from the cloaca collected. The yeasts isolated from cloacae birds were studied by phenotypic and genotypic methods. The production of extracellular enzymes as virulence factors (protease and phospholipase) was performed too. From the total of parrots studied, 10 strains of yeasts were isolated. Nine of the strains belonged to the specie Cryptococcus albidus var. albidus and one sample belonged to the specie Cryptococcus laurentti. The extracellular enzymes research demonstrated that $80 \%$ of the isolates were phospholipase producers and all of them were protease positives. These results suggest that not just the environment but also the birds of $A$. aestiva genus may be the carriers of $C$. albidus. We point out that the strains produced virulence factors. This is the first report of the isolation of $C$. albidus var. albidus of $A$. aestiva parrots and to assert that this bird is a special ecological niche of capped yeast.
\end{abstract}

Keywords: Yeasts; Psittacidae; Cryptococcus albidus; Virulence factors

\section{Introduction}

Cryptococcosis is one of the leading community-acquired opportunistic mycoses and is associated with high mortality and morbidity. The major predisposing factors are cellular immune defects like those affecting patients with AIDS, with malignancies, or receiving corticosteroid or immunosuppressive therapy [1-3]. This disease is the great relevance in the medical mycology $[4,5]$.

The yeasts of the complex Cryptococcus present 70 species and most of them are related to the environment. From these, Cryptococcus neoformans and Cryptococcus gattii are considered pathogenic [6]. Cryptococcus albidus and C. laurentii are being clinically highlighted due to the increase of the frequency. Cryptococccus albidus already been isolated from blood, lung, skin, and cerebrospinal fluid [7].

It is possible to verify that several studies evidencing the importance of bird dropping as a suitable substrate for the growth of yeasts and filamentous fungi [8-15]. Birds easily conduct the agent in the environment through its feces and become a zoonotic problem due to its proximity with the humans, explained by the fact that it is a peridomestic animal. However, little is known about the existence of $C$. albidus var. albidus in wild birds and from captivity.

Many reports related the association of the Cryptococcus with the environment as well as the correlation of them with animals mainly with birds like pigeons. Pigeons conduct C. neoformans in the environment through their faeces and become a zoonotic problem due to their proximity with the humans. The literature is rare about the presence of Cryptoccocus complex in wild and captivity birds $[10,11,13,14]$.

Brazil has one of the largest bird species in the world, with endemic species, has an undeniable importance in the global biodiversity scenario [16], which makes the country one of the most important in diversity and conservation $[17,18]$. Psittacids have a great representation in the country, of which 23 are endemic and occur only in Brazil $[18,19]$. The group is known for large macaws, beautiful parrots capable of mimicking human voices and colorful parakeets [17].

Amazona aestiva, which is commonly called Turquoise-fronted parrot is a bird of the family Psittacidae. This bird has approximately $38 \mathrm{~cm}$, weighs about 400 grams and its life expectancy is 80 years. Their nests are found in the cavities of trees and fruit bushes. It is found in Bolivia, Paraguay and northern of Argentina. In Brazil, this bird is more

*Corresponding author: Diniz Pereira Leite Júnior, School of Dentistry, Universidade de São Paulo (USP), Av. Lineu Prestes, 2.227, São Paulo - SP, Brazil, Tel: +556536158809; E-mail: djbiologico@gmail.com

Received November 06, 2017; Accepted November 16, 2017; Published November 17, 2017

Citation: Nascimento DC, Paula CR, Ruiz LS, Domaneschi C, Navarro BS, et al (2017) Cryptococcus albidus var. albidus Isolated from Turquoise-Fronted Parrots (Amazona aestiva: Psittacidae) Kept in Captivity: A Probable Reservoir Ecological of Fungal Specimen. J Vet Sci Technol 8: 489. doi: 10.4172/2157-7579.1000489

Copyright: @ 2017 Nascimento DC, et al. This is an open-access article distributed under the terms of the Creative Commons Attribution License, which permits unrestricted use, distribution, and reproduction in any medium, provided the original author and source are credited. 
frequent in the North and Northeast regions, but can still be observed in the midwest, south-east and south regions of the country, in the humid forests, in rivers, and closed borders. This species is the most popular of the Psittacidae family for being sociable, for scoring imitate human sounds and be easily found $[18,19]$.

Since 1990, A. aestiva is being seen in São Paulo city, probably from escapes captivity and migration to large urban centers. This migration was due to deforestation resulting from the lack of food for these kites [20]. Possibly the most popular of all Brazilian birds and one of the biggest targets of the illegal trade of wild animals in the world [16].

The aim of this study was to perform the isolation of yeasts belonging to the genus Cryptococcus from cloacae of parrots of the genus Amazona aestiva, as well as to perform the phenotypic and genotypic identification and investigation of presence of the virulence factors (protease and phospholypase).

\section{Materials and Methods}

\section{Ethical approval}

All applicable international, national, and/or institutional guidelines for the care and use of animals were followed. All procedures performed in studies involving animals were in accordance with the ethical standards of the institution or practice at which the studies were conducted (CEUA/127).

The collected materials of cloacae were originated from 40 parrots of the genus A. aestiva without age or gender defined. These birds are captivity in a private captivity located in the São Paulo, Brazil. The parrots used in this study did not present any visible sign of disease. The parrots captivity had two separated environments; the indoor area, with many closed enclosures, and the outdoor area, that was an open place delimited by fences with some places protect of rain and wind.

\section{Collecting material}

The analyzed material was collected from two regions of the birds: crops and cloacae. The birds were anesthetized to perform this procedures and before collecting the material from the crop, the birds have it washed with $5 \mathrm{~mL}$ of physiological saline $0.9 \%$ sterile through the introduction of a urethral sound sterile number 5 or 6 . The sounder was introduced initially in the oral cavity of the bird towards the esophagus until the crop. Before collecting the material from cloacae, it was previously cleaned with $70 \%$ alcohol. To obtain samples of the cloacae, was used swab moistened with physiological saline $(0.9 \%)$ being kept refrigerated until the inoculation on Petri dish with Sabouraud dextrose agar (Difco, USA) with chloramphenicol $0.25 \%$. The samples were performed in triplicate and incubated from 7 to 15 days at $30^{\circ} \mathrm{C}$. All the yeasts samples were isolated in tubes containing the Sabouraud dextrose agar (Difco, USA) with chloramphenicol $0.25 \%$. Morphological and physiological tests were did according to Kurtzman [6].

\section{Identification of yeasts}

The strains were identified according the manual the yeasts it may be described: the India ink test to verify the morphology of the yeast as well as the formation or not of the polysaccharide capsule; test of urease production in which the yeasts were inoculated in Christensen medium to verify the production of enzymes by the yeast. Other tests were performed as growth in medium canavanine glycine bromothymol (CGB) to observed blue cobalt colour; phenol oxidase production in a medium containing dopamine (dark brow-black colour). Additional tests were realized to identify the three varieties of C. albidus: assimilation of maltose, melizitose, L-tartrate, L-lysine; growth at $35^{\circ} \mathrm{C}$; growth at yeast extract agar (Difco, USA) to observed the colour of the strains and starch production [6].

The species identification was confirmed by polymerase chain reaction (PCR) and sequencing of ITS region, employing primers pairs ITS1/ITS2. Sequencing reactions were performed in automatic sequencer 3130 Genetic Analyzer (Life Technologies, CA, USA), by capillary electrophoresis, employing the Kit Big Dye Terminator Cycle Sequencing V3.1 (Life Technologies, CA, USA), and analyzed by the Sequencing Analysis v 5.3.1 and SeqScape v 2.6. Sequencing was performed in order to confirm the identity of the amplicons with sequences from the database of NCBI GenBank.

All the experiments followed standards strains C. gattii ATCC 56990 e C. neoformans ATCC 90112.

The production of phospholipase and proteinase were also investigated. In the first test, the strains were inoculated in a phospholipase agar medium with yolk and incubated at $25^{\circ} \mathrm{C}$ up until 15 days [21]. In the test to verify the protease production, the strains were inoculated on a medium containing bovine albumin fraction $\mathrm{V}$ (Sigma, EUA) and incubated at $25^{\circ} \mathrm{C}$ up until 15 days [22]. The value of the enzymatic activity (PZ) was obtained by calculating the ratio between the diameters of the colony and the one zone by the colony and the precipitation/degradation zone. The results of the extracellular enzyme production were analyzed according to the pattern described by Price et al. and Rüchel et al. [21,22]. A Pz value of $1.0 \mathrm{~mm}$ represent the absence of enzymatic activity while values between $0.64 \mathrm{~mm}$ and $1.0 \mathrm{~mm}$ reflect positive activity and with values less than $0.64 \mathrm{~mm}$ suggesting strongly positive enzymatic activity.

Statistical analysis was performed to assess the significance or absence of the number of isolated indoor and outdoor area (Test quisquare $-P<0.05)$.

All applicable international, national, and/or institutional guidelines for the care and use of animals were followed. All procedures performed in studies involving animals were in accordance with the ethical standards of the institution or practice at which the studies were conducted (Ethical approval protocol CEUA/127, Institute of Biomedical Sciences/University of São Paulo, adopted on 29 November 2011).

\section{Results}

The 40 birds studied, yeasts belonging to the complex Cryptococcus were isolated from 10 birds (25\%). The majority of them (90\%) were identified as Cryptococcus albidus (Saito) CE Skinner and one as Cryptococcus laurentii (Kufferath) CE Skinner.

The isolates that grew on yeast extract agar presented color cream to pinkish-cream and smooth surface, being that one strain presented pale grayish-cream color and mucous aspect. All the strains presented capsule or incipient capsule.

The growth on CGB medium all the yeasts did not demonstrated blue-cobalt colour and one strain $C$. laurentii revealed light blue color. On medium containing dopamime, all strains presented a light yellow colour. These tests are positive to C. neoformans or to C. gattii, blue cobalt colour and dark brown colour, respectively.

Additional tests revealed that the variety of C. albidus was var. albidus: assimilation positive for maltose, melizitose, L-tartrate and 
Citation: Nascimento DC, Paula CR, Ruiz LS, Domaneschi C, Navarro BS, et al. (2017) Cryptococcus albidus var. albidus Isolated from TurquoiseFronted Parrots (Amazona aestiva: Psittacidae) Kept in Captivity: A Probable Reservoir Ecological of Fungal Specimen. J Vet Sci Technol 8: 489. doi: 10.4172/2157-7579.1000489

Page 3 of 5

L-lysine; growth at yeast extract agar and with yellow color; growth at $35^{\circ} \mathrm{C}$; and starch production.

According Kurtzman et al. nine strains belong to C. albidus var. albidus and only one strain belong to the specie C. laurentii [6]. Through the analysis of the ITS region nine of the samples were identified as $C$. albidus (99-100\% identity) and one as C. laurentti, (99\% identity).

The phospholipase production was observed in $80 \%$ of the strains as high producers and one strain of $C$. laurentii and one strain of $C$. albidus not produce this enzyme. Similar results could be observed in protease production because the strains were high producers in $80 \%$ and $20 \%$ were only producers.

Among the strains identified as Cryptococcus, 6 (60\%) were originated from birds that were found in the indoor area and 4 (40\%) were originated from animals of the outdoor area as it is shown in the Table 1. There was no significant difference between the isolation in indoor / outdoor areas (Test qui-square- $P<0.05$ )

\section{Discussion}

The relation Cryptococcus-bird has ecological and epidemiological relevancy and widely studied. There are a great number of publications about this topic. From the first description of the isolation of the yeast from the pigeon's excretas by Emmons [23], many other researches were published highlighting the prevalence of the fungus in the faeces of columbiformes and other birds [24], in different places around the world. Carter and Baroni et al. linked the presence of the yeast with nests and chicks $[10,25]$.

The isolation of yeasts belonging to the genus Cryptococcus is frequent when related to organic material principally from bird's faeces. However, the recuperation of the samples belonging to this genus, from the cloacae of Psittacidae, object of this study, is a factor still little studied.

The difficulty of the isolation of the agent may also observed in many studies, and some factors that influence these isolations are growth of filamentous fungi, temperature changes after taking the sample to arrive at the laboratory, and humidity [26-29]. This fact occurs because dried bird droppings have fertility characteristics for fungal species growth due to high concentrations of nitrogenous bases and, as they become old, they contain higher concentrations of fungi than when they have recently been eliminated $[14,15,30]$.

In this present study, the parrots had shown being capable of lodging C. albidus var. albidus in the cloacae and may disseminate it in the environment through the faeces. Other studies also isolated yeasts from the parrots but not from $A$. aestiva genus [31,32]. It is possible to verify many reports that describe the link of yeasts belonging to the complex Cryptococcus with the environment as well as the correlation of them with the animals. A retrospective of scientific studies related birds and yeasts in different countries and the geographical distribution of etiological agents can be observed and analyzed in this study (Table 2).

It is relevant to mention that the C. albidus has been reported in various clinical materials and causing diverse infections, mainly in immunocompromised patients $[42,43]$. Few cases of animal C. albidus infections have also been reported [44]. It should be emphasized that in this study none of the birds had any clinical manifestation.

The major number of researches are restricted to species $C$. neoformans and C. gattii and their relation with the environment. Other species of the genus as $C$. albidus and C. laurentii are less described without considering their relevance as pathogens and their interactions with the environment. In a study performed with samples originated from the cloacae of Psittacidae, González-Hein et al. isolated strains of C. albidus and C. laurentii [45]. However, this study did not refer to the genus $A$. aestiva. In our study, the isolated strains were phenotypically and biochemically identified as C. albidus var. albidus and C. laurentii, being that the first was recovered in nine of the ten carrier parrots.

Other varieties of C. albidus (C. albidus var. ovalis and C. albidus var. kuetzinguii) do not produce starch and the variety C. kuetzinguii does not assimilate maltose or melezitose, tests that are positive for $C$. albidus var. albidus. Cryptococcus albidus var. kuetzinguii were only isolated in Europe from environmental sources [46] and C. albidus var. ovalis was obtained from goat dung in Pakistan. The geographic distribution of C. albidus var. albidus is wide [6].

All isolates of C. albidus var. albidus produced phospholipase and protease at a high level. A special clinical relevance is point out because of the fact that these enzymes are factors of virulence $[47,48]$.

Cryptococcus albidus has been reported as an antagonist of certain postharvest pathogenic fungi [49]. This fact makes us believe that in these A. aestiva faeces studied, the unike presence of $C$. albidus may have inhibited the growth of other fungal species such as $C$. neoformans. The C. albidus strains are less susceptible to azole antifungals, important factor, but it is sensitive to amphotericin B [6].

Slide agglutination experiments with strains of C. neoformans factor shown that antigenic formulae of $C$. albidus strains were similar to serotype A of C. neoformans [50]. These findings reveal the antigenic proximity of C. albidus with C. neoformans serotype A.

The results obtained in this research confirm the role and the relevance of the parrots from the genus A. aestiva as a source of dissemination of yeasts in the environment. Most of the yeasts were producers of the extracellular enzymes proteinase and phospholipase, considered as virulence factors of microorganisms. By the literature and by the interesting results of this research, the specie $C$. albidus should be better studied referring to the epidemiology and interaction C. albidus-environment-human.

Apparently birds seen as healthy can act as hosts for pathogenic microorganisms to defecate and contaminate the environment with several yeast genera that present zoonotic potential, so it is important to mention the relevance of avian zoonosis because these are infections that often remain asymptomatic in birds, misdiagnosed as healthy, making it difficult to determine the correct diagnosis and subsequent treatment, thus increasing the chances of transmission to bird keepers, zoo visitors, pet store workers, and pet owners.

\begin{tabular}{|c|c|c|}
\hline Birds & Area & \multicolumn{1}{|c|}{ Identification } \\
\hline 2 & Indoor, $\mathrm{n}^{\circ} 15$ & C. albidus var. albidus \\
\hline 3 & Indoor, $\mathrm{n}^{\circ} 15$ & C. albidus var. albidus \\
\hline 15 & Indoor, $\mathrm{n}^{\circ} 03$ & C. albidus var. albidus \\
\hline 16 & Indoor, $\mathrm{n}^{\circ} 10$ & C. albidus var. albidus \\
\hline 19 & Indoor, $\mathrm{n}^{\circ} 12$ & C. albidus var. albidus \\
\hline 21 & Indoor, $\mathrm{n}^{\circ} 13$ & C. albidus var. albidus \\
\hline 26 & Outdoor & C. laurentii \\
\hline 29 & Outdoor & C. albidus var. albidus \\
\hline 31 & Outdoor & C. albidus var. albidus \\
\hline 34 & Outdoor & C. albidus var. albidus \\
\hline
\end{tabular}

Table 1: Relation of the birds, local of isolation and identification of the strains and yeasts originating from parrots of the genus $A$. aestiva. 
Citation: Nascimento DC, Paula CR, Ruiz LS, Domaneschi C, Navarro BS, et al. (2017) Cryptococcus albidus var. albidus Isolated from TurquoiseFronted Parrots (Amazona aestiva: Psittacidae) Kept in Captivity: A Probable Reservoir Ecological of Fungal Specimen. J Vet Sci Technol 8: 489. doi: 10.4172/2157-7579.1000489

Page 4 of 5

\begin{tabular}{|c|c|c|c|c|c|}
\hline Authors/reference & $\begin{array}{c}\text { Cityl } \\
\text { Coutries }\end{array}$ & $\begin{array}{c}(\mathrm{N}) \\
\text { Species birds studied }\end{array}$ & $\begin{array}{l}\text { Patology/Clinical signs and } \\
\text { Substrate }\end{array}$ & Etiological agent & Prevalent agent \\
\hline Filiú et al. [12] & $\begin{array}{c}\text { Mato Grosso do } \\
\text { Sul/Brazil }\end{array}$ & $\begin{array}{l}\text { (20) Passeriformes, Psittaci- } \\
\text { formes, Columbiformes. }\end{array}$ & Faecal samples & Cryptococcus spp. & $\begin{array}{l}\text { Cryptococcus } \\
\text { neoformans }\end{array}$ \\
\hline Malik et al. [33] & $\begin{array}{l}\text { Sydney/ } \\
\text { Australia }\end{array}$ & $\begin{array}{c}\text { (15) Psittacus erithacus, } \\
\text { Eclectus roratu, Alisterus } \\
\text { scapulari, Aptery australis, } \\
\text { Cacatua galerita, C. tenuirostris, } \\
\text { C. roseicapilla and Columba livia }\end{array}$ & $\begin{array}{l}\text { Infection respiratory tract } \\
\text { and lesions/cytological and } \\
\text { histological preparations }\end{array}$ & Cryptococcus spp. & $\begin{array}{l}\text { Cryptococcus grubii and } \\
\text { C. bacillisporus }\end{array}$ \\
\hline Raso et al. [34] & $\begin{array}{l}\text { São Paulo/ } \\
\text { Brazil }\end{array}$ & $\begin{array}{c}\text { (7). Charmosyna papou. Lorius } \\
\text { lorry, Trichoglossus glodiei, } \\
\text { Psittacula kdrameri, psittacul } \\
\text { erithacus }\end{array}$ & $\begin{array}{c}\text { Incoordination paralysis and } \\
\text { superficial lesions/Faeces, organ } \\
\text { fragments and aspirated biopsy } \\
\text { samples }\end{array}$ & Cryptococcus spp. & Cryptoccoccus gattii \\
\hline Abegg et al. [35] & $\begin{array}{l}\text { Rio Grande do } \\
\text { Sul/Brazil }\end{array}$ & $\begin{array}{l}\text { (38). Obtained from } \\
\text { psittaciformes: Psittacidae, } \\
\text { Cacatuidae and Psittacula. }\end{array}$ & Faecal samples & Cryptococcus spp. & $\begin{array}{l}\text { Cryptococcus grubii } \\
\text { Cryptococcus gattii }\end{array}$ \\
\hline Cafarchia et al. [36] & Bari/ltaly & $\begin{array}{l}\text { (1.721) migratory and cought } \\
\text { birds }\end{array}$ & Cloacae samples & $\begin{array}{l}\text { Candida spp, Cryptococcus } \\
\text { spp, Rhodotorula spp. }\end{array}$ & $\begin{array}{l}\text { Rhodotorula rubra and } \\
\text { Cryptococcus albidus }\end{array}$ \\
\hline Cafarchia et al. [37] & Bari/ltaly & $\begin{array}{l}\text { (768) Obtained birds of prey, } \\
\text { Passeriformes, migratory birds } \\
\text { and aviaries birds. }\end{array}$ & Cloacae samples & $\begin{array}{l}\text { Candida spp., Cryptococcus } \\
\text { spp., Trichosporon spp., } \\
\text { Rhodotorula spp., and } \\
\text { Saccharomyces spp. }\end{array}$ & $\begin{array}{l}\text { Candida albicans, } \\
\text { Cryptococcus albidus, C. } \\
\text { laurentii, C. neoformans. }\end{array}$ \\
\hline Lugarini et al. [38] & Paraná/Brazil & $\begin{array}{l}\text { (141) Passeriformes and } \\
\text { Psittaciformes }\end{array}$ & Faecal samples & Cryptococcus spp. & $\begin{array}{l}\text { Cryptococcus grubii } \\
\text { Cryptococcus gattii }\end{array}$ \\
\hline Santos et al. [29] & Paraná/Brazil & $\begin{array}{c}\text { (29). Amazona aestiva, } \\
\text { Aratinga solsistialis, Nymphicus } \\
\text { hollandicus }\end{array}$ & $\begin{array}{l}\text { breathing problems/ oral cavity/ } \\
\text { cloacae samples }\end{array}$ & $\begin{array}{l}\text { Candida spp. } \\
\text { Cryptococcus spp. }\end{array}$ & $\begin{array}{l}\text { Cryptococcus } \\
\text { neoformans }\end{array}$ \\
\hline Brilhante et al. & Ceará/Brazil & (60) Nymphicus hollandicus & $\begin{array}{c}\text { Oral cavity, crop and cloacae } \\
\text { samples }\end{array}$ & $\begin{array}{l}\text { Candida spp., Rhodotorula } \\
\text { spp. and Trichosporon spp. }\end{array}$ & Candida albicans \\
\hline $\begin{array}{l}\text { González-Hein et al. } \\
\text { [39] }\end{array}$ & Santiago/Chile & (113) Captive species of birds & Droppings samples & Cryptococcus spp. & $\begin{array}{l}\text { Cryptococcus albidus, } \\
\text { C. neoformans and } C . \\
\text { uniguttulatus. }\end{array}$ \\
\hline Marinho et al. & $\begin{array}{l}\text { São Paulo/ } \\
\text { Brazil }\end{array}$ & (36) Passeriformes (passerines) & Droppings samples & $\begin{array}{l}\text { Penicillium spp., Aspergillus } \\
\text { spp., Candida spp., } \\
\text { Trichosporon spp. and } \\
\text { Cryptococcus spp. }\end{array}$ & $\begin{array}{c}\text { Penicillium spp., } \\
\text { Cryptococcus gattii and } C . \\
\text { neoformans }\end{array}$ \\
\hline Mendes et al. [15] & $\begin{array}{l}\text { Rio Grande do } \\
\text { Sul/Brazil }\end{array}$ & (50) Different species of birds & Faecal samples & $\begin{array}{l}\text { Malassezia spp., Candida } \\
\text { spp., Trichosporon spp., } \\
\text { Geotrichum spp., Asper-gillus } \\
\text { spp., Penicillium spp. and } \\
\text { Cryptococcus spp. }\end{array}$ & $\begin{array}{c}\text { Candida albicans } \\
\text { Cryptococcus lauurentii }\end{array}$ \\
\hline Dynowska et al. [40] & $\begin{array}{l}\text { Warnia/ } \\
\text { Poland }\end{array}$ & (450) Charadriiformes (seagulls) & Cloacae samples & $\begin{array}{l}\text { Candida spp, Cryptococcus } \\
\text { spp. and Rhodotorula spp. }\end{array}$ & $\begin{array}{l}\text { Candida albicans } \\
\text { Cryptococcus satoi, C. } \\
\text { neoformans. }\end{array}$ \\
\hline Abbas et al. [41] & Baghdad/Iraq & $\begin{array}{l}\text { (100) Birds: pigeon, pet bird and } \\
\text { chicken. }\end{array}$ & Faecal samples & Moulds and Yeasts & $\begin{array}{l}\text { Penicillium spp. } \\
\text { Cryptococcus } \\
\text { neoformans }\end{array}$ \\
\hline $\begin{array}{l}\text { *Simi et al. } \\
\text { (personal communi- } \\
\text { cation - Out/2017) }\end{array}$ & $\begin{array}{l}\text { Mato Grosso/ } \\
\text { Brazil }\end{array}$ & $\begin{array}{l}\text { (149) Birds of prey and } \\
\text { Psittaciformes. }\end{array}$ & Faecal samples & Moulds and yeasts & $\begin{array}{c}\text { Aspergillus niger, Candida } \\
\text { kefyr and Cryptococcus } \\
\text { albidus }\end{array}$ \\
\hline${ }^{\star *}$ Nascimento et al. & $\begin{array}{l}\text { São Paulo/ } \\
\text { Brazil }\end{array}$ & (40) Amazona aestiva & Cloacae samples & Cryptococcus spp. & $\begin{array}{c}\text { Cryptococcus albidus and } \\
\text { C. laurentii }\end{array}$ \\
\hline
\end{tabular}

Table 2: Geographic distribution of yeasts that cause infection in birds, etiological agents and their dominant pathogens in the study areas.

\section{Conclusion}

More studies involving wild birds as A. aestiva are necessary because they could be reservoirs and disseminators of these yeasts in the environment. This is the first research about the isolation of $C$. albidus var. albidus from the cloacae of parrots of the genus $A$. aestiva in Brazil.

\section{Acknowledgments}

The authors express their thanks to Mr. Joseph Moutran the availability of the collect area, and to Coordenação de Aperfeiçoamento de Pessoal de Nível Superior (CAPES), Conselho Nacional de Desenvolvimento Científico e Tecnológico (CNPQ) and Fundação de Amparo à Pesquisa do Estado de São Paulo (FAPESP) for their financial support.

\section{Conflict of Interest}

The authors declare that there are no conflicts of interest.

\section{References}

1. Lacaz CS, Porto E, Martins JEC, Heins-Vaccari EM, Melo NT (2002) Treaty of Medical Mycology Lacaz. Sarvier, São Paulo, p: 1104.

2. Bicanic T, Harrison TS (2005) Cryptococcal meningitis. Br Med Bull 72: 99-118.

3. Pedroso RS, Candido RC (2006) Laboratory Diagnosis of Cryptococcosis. Newslab 77

4. Perfect JR, Casadevall A (1998) Cryptococcus neoformans. ASM Press Washington, p: 541.

5. Molter CM, Zuba JF, Papendick R (2014) Cryptococcus gattii Osteomyelitis and Compounded Itraconazole Treatment Failure in a Pesquet's Parrot (Psittrichas Fulgidus). J Zoo WildI Med 45: 127-133. 
Citation: Nascimento DC, Paula CR, Ruiz LS, Domaneschi C, Navarro BS, et al. (2017) Cryptococcus albidus var. albidus Isolated from TurquoiseFronted Parrots (Amazona aestiva: Psittacidae) Kept in Captivity: A Probable Reservoir Ecological of Fungal Specimen. J Vet Sci Technol 8: 489. doi: 10.4172/2157-7579.1000489

6. Kurtzman CP, Fell JW, Boekhout T (2011) The yeasts: a taxonomic study. 5th edn. Elsevier, New York, p: 2080

7. Heitman J, Kozel TR, Kwon-Chung KJ, Perfect JR, Casadevall A (2011) Cryptococcus from human pathogen to model yeast. ASM Press, Washington DC, p: 620.

8. Reolon A, Perez LRR, Mezzarl A (2004) Prevalence of Cryptococcus neoformans in urban pigeons of Porto Alegre (RS), Brazil. J Bras Patol Med Lab 40: 293-298.

9. Chee HY, Lee KB (2005) Isolation of Cryptococcus neoformans var. grubi (serotype A) from pigeon droppings in Seoul, Korea. J Microbiol 43: 469-472.

10. Baroni FA, Paula CR, Silva EG, Viani FC, Rivera ING, et al. (2006) Cryptococcus neoformans strains isolated from church towers in Rio de Janeiro city, RJ, Brazil. Rev Inst Med trop S Paulo 48: 71-75

11. Nielsen K, Obaldia AL, Heitman J (2007) Cryptococcus neoformans mates on pigeon guano: implications for the realized ecological niche and globalization. Eukaryot Cell 6: 949-959.

12. Filiú WFO, Wanke B, Agüena SM, Vilela VO, Macedo RCL, et al. (2002) Avian habitats as sources of Cryptococcus neoformans in the city of Campo Grande, Mato Grosso do Sul, Brazil. Rev Soc Bras Med Trop 35: 591-595.

13. Lázera MS, Igreja RP, Wanke BC (2010) Criptococose. In: Sidrim JJC Rocha MFG (eds.), Medical Mycology in the Light of Contemporary Authors. Guanabara Koogan, Rio de Janeiro, pp: 252-263.

14. Elhariri M, Hamza D, Elhelw R, Refai M (2015) Lovebirds and Cockatiels Risk Reservoir of Cryptococcus neoformans, a Potential Hazard to Human Health. J Vet Sci Med Diag 4: 6.

15. Mendes JF, Albano APN, Coimbra MAA, Ferreira GF, Gonçalves CL, et al. (2014) Fungi isolated from the excreta of wild birds in screening centers in Pelotas, RS, Brazil. Rev Inst Med Trop Sao Paulo 56: 525-528.

16. Brazil (2012) Ministry of environment. Acessed on: 17 July 2017.

17. Sick H (2001) Ornitologia Brasileira. 4th edn. Editora Nova Fronteira: Rio de Janeiro, p: 862

18. Piacentini VQ, Aleixo A, Agne CE (2015) Annotated checklist of the birds of Brazil by the Brazilian Ornithological Records Committee. Bras J Ornithol 23: 91-298.

19. Clements JF, Schulenber TS, lliff MJ, Robertson D, Fredericks TA, et al. (2017) The eBird/Clements checklist of birds of the world: v2016. Accessed on 12 Oct 2017.

20. Alderton D (2003) The ultimate encyclopedia of caged and aviary birds. Hernes House, New York, USA, p: 230

21. Price MF, Wilkinson ID, Gentry LO (1982) Plate methods for detection of phospholipase activity in Candida albicans. Sabouraudia 20: 15-20.

22. Rüchel R, Tegeler R, Trost M (1982) A comparison of secretory proteinases from different strains of Candida albicans. Sabouraudia 20: 233-244.

23. Emmons CW (1955) Saprophytic sources of Cryptococcus neoformans associated with the pigeon (Columba livia). Am J Hyg 62: 227-232.

24. Hedayati MT, Mayahi S, Fakhar M, Shokohi T, Majidi M (2011) Cryptococcus neoformans isolation from Swallow (Hirundo rustica) excreta in Iran. Rev Inst Med Trop Sao Paulo 53: 125-127.

25. Carter GR (1988) Fundamentals of Bacteriology and Veterinary Mycology. Roca, São Paulo.

26. Mancianti F, Nardoni S, Ceccherelli R (2001) Occurrence of yeasts in psittacines droppings from captive birds in Italy. Mycopathologia 153: 121-124.

27. Kobayashi CC, Souza LK, Fernandes OF, Brito SC, Silva AC, et al (2005) Characterization of Cryptococcus neoformans isolated from urban environmental sources in Goiânia, Goiás State, Brazil. Rev Inst Med Trop Sao Paulo 47: 203-207.

28. Rezende C, Munhóz CJM, Almeida GG (2008) Investigação ambiental de Cryptococcus neoformans na cidade de Votuporanga. Newslab, p: 87

29. Santos LL, Ferreira FM, Lopes SF, Condas LA, Muro MD, et al. (2009) Search for Cryptococcus neoformans and Candida spp. In Excretas De Psitacídeos and Passeriformes Cativos. Arq Ciênc Vet Zool Unipar, Umuarama 12: 5-9.

30. Johnston SA, Voelz K, May RC (2016) Cryptococcus neoformans Thermotolerance to Avian Body Temperature Is Sufficient For Extracellular Growth But Not Intracellular Survival In Macrophages. Sci Rep 6: 20977.

31. López-Martínez R, Castañón-Olivares LR (1995) Isolation of Cryptococcus neoformans from bird droppings, fruits and vegetables in Mexico city. Mycopathologia 129: 25-28.

32. Pal M (2005) Prevalence of Cryptococcus neoformans in faecal matter of caged parrots. Dis Zoo Anim 42: 130-133.

33. Malik R, Krockenberger MB, Gross G, Doneley R, Madill DN, et al. (2003) Avian cryptococcosis. Med Mycol 41: 115-124.

34. Raso TF, Werther K, Miranda ET, Mendes-Giannini JS (2004) Cryptococcosis outbreak in psittacine birds in Brazil. Med Mycol 42: 355-362.

35. Abegg MA, Cella FL, Faganello J, Valente P, Schrank A, et al. (2006) Cryptococcus neoformans and Cryptococcus gattii isolated from the excreta of Psittaciformes in a Southern Brazilian Zoological Garden. Mycopathologia 161: 83-91.

36. Cafarchia C, Camarda A, Romito D, Campolo M, Quaglia NC, et al. (2006) Occurrence of yeasts in cloacae of migratory birds. Mycopathologia 161: 229-234

37. Cafarchia C, Romito D, Coccioli C, Camarda A, Otrant D (2004) Phospholipase activity of yeasts from wild birds and possible implications for human disease. Med Mycol 46: 429-434.

38. Lugarini C, Gobebel CS, Condas LA, Muro MD, Farias MR, et al. (2008) Cryptococcus neoformans isolated from passerine and psittacidae bird excreta in State of Paraná, Brazil. Mycopathologia 166: 61-69.

39. González-Hein G, González J, Díaz MC (2010) Detection of yeasts in cloacae of two species of native psittacine birds in a Chilean rehabilitation center. Arch Med Vet 42: 105-108.

40. Dynowska M, Biednkiewicz A, Kisicka I, Eddys E, Kubiak D, et al. (2015) Epidemiological importance of yeasts isolated from the beak and cloaca of healthy Charadriiformes. Bull Vet Inst Pulawy 59: 65-69.

41. Abbas MS, Yassein SN, Khalaf JM (2017) Isolation and identification of some important mycological isolates from dropping of birds in Baghdad. J Entomol Zool Stud 5: 671-673.

42. Narayan S, Batta K, Colloby P, Tan CY (2000) Cutaneous Cryptococcus infection due to $\mathrm{C}$. albidus associated with Sézary syndrome. $\mathrm{Br} \mathrm{J}$ Dermatol 143: $632-634$

43. De Castro LE, Sarraf OA, Lally JM, Sandoval HP, Solomon KD, et al. (2005) Cryptococcus albidus keratitis after corneal transplantation. Cornea 24: 882883.

44. Labrecque O, Sylvestre D, Messier S (2005) Systemic Cryptococcus albidus infection in a Doberman Pinscher. J Vet Diagn Invest 17: 598-600.

45. Gonzales-Hein G, Gonzales-Hein J, Jarabrán MCD (2010) Isolation of Cryptococcus neoformans in Dry Droppings of Captive Birds in Santiago, Chile. $\mathrm{J}$ Avian Med Surg 24: 227-236

46. Gadanho M, Almeida JM, Sampaio JP (2003) Assessment of yeast diversity in a marine environment in the south of Portugal by microsatellite-primed PCR. Antonie Van Leeuwenhoek 84: 217-227.

47. Vidotto V, Melhem MSC, Pukinskans S, Aoki S, Carraga C, et al. (2005) Extracellular enzymatic activity and serotipe of Cryptococcus neoformans strains isolated from AIDS patients in Brazil. Rev Iberoam Micol 22: 29-33.

48. Campos FL, Baroni FA (2010) Isolates of Cryptococcus neoformans, C. gatti and C. laurentii protease and phospholipase producers. J Trop Pathol 39: 83-89.

49. Calvo J, Calvente V, Orellano ME, Benuzzi D, Tosetti MIS (2003) Improvement in the biocontrol of postharvest diseases of apples with the use of yeast mixtures. BioControl 48: 579-593.

50. Ikeda R, Sugita T, Shinoda T (2000) Serological relationships of Cryptococcus spp.: distribution of antigenic factors in Cryptococcus and intraspecies diversity. J Clin Microbiol 38: 4021-4025. 